\title{
COLLATERAL ESTOPPEL: APPLICATION TO ACTIONS BETWEEN FORMER CODEFENDANTS
}

As a result of injuries sustained in a highway collision, $A$ brings an action against $B$ and $C$ for negligence. A consent judgment is entered against $B$ and $C$. Subsequently, $B$ sues $C$ for negligence in the same collision. Can $C$ successfully interpose the defense of collateral estoppel on the theory that the prior consent judgment conclusively establishes $B$ 's negligence?

In Pack v. McCoy, ${ }^{1}$ the North Carolina Supreme Court recently upheld such a defense, stating that a judgment against all defendants in a negligence action necessarily establishes the negligence of each in any future proceeding. ${ }^{2}$ The court applied this broad rule to a situation in which the parties to be bound had not been adversaries and the issue of negligence had not been litigated. The dissent forcefully contended that state precedent should be overruled, pointing out that this holding is contrary to the weight of authority. ${ }^{3}$

The doctrine of collateral estoppel minimizes litigation by treating as conclusively established all facts that were litigated and determined between the same parties in a previous suit on a different cause of action. ${ }^{4}$ Following this functional definition, the majority of courts apply the doctrine to former co-defendants in a suit on independent questions only if they were adversaries in the first action. ${ }^{5}$ It is important to note that the Pack case involved an independent action between former coparties, which should be distinguished from suits for indemnity or contribution. In an independent suit the former co-defendant asserts a

\footnotetext{
${ }^{2} 25$ I N.C. 590 , II2 S.E.2d II8 (1960).

${ }^{2} I d$. at 593 , I 12 S.E.2d at 121 .

${ }^{3} I d$, at 594, I I 2 S.E.2d at $\mathrm{I} 2 \mathrm{r}$. Justice Bobbitt urged that Lumberton Coach Co. v. Stone, 235 N.C. 619,70 S.E.2d 673 (1952), the only state precedent, be overruled.

4See Polarsky, Collateral Estoppel, 39 Iowa L. Rev. 2 I7, 2 I9-20 (1954); RestateMENT, JUDGMENTS $\S 45$ (I942). See generally Cromwell v. Sac, 94 U.S. 35 I (1876).

Res judicata is the generic term covering merger, bar, direct estoppel, and collateral estoppel. See Restatement, JUdGments, Introductory Note to chapter 3, (1942). When contending that a former judgment affects the outcome of the case, a party will plead res judicata, which is usually an affirmative defense. Cf., FED. R. CIv. P. 8(c); Clark, Code Pleading 6ri-12 (2d ed. 1947).

I FREEMAN, JUDGMENTS $\$ 424$ (5th ed. x 925 ); see e.g., Clark's Adm'x v. Rucker, 258 S.W.2d 9 (Ky. 1953); Bunge v. Yager, 236 Minn. 245, 52 N.W.2d 446 (1952); RESTATEMENT, JUDGMENTS $\$ 82$ (1942).
} 
claim that he has irrespective of the former judgment; in suits for contribution and indemnity the claim is a direct result of judicial determination of liability. Although policy considerations unique to contribution and indemnity cases have resulted in judicial disagreement over the applicability of collateral estoppel to these actions, ${ }^{6}$ nearly all courts apply the adversary requirement to independent suits between former co-parties. ${ }^{\top}$

\footnotetext{
${ }^{6}$ In the contribution action often the co-defendant who lost in the first action will be suing one who put up a successful defense. A rule which would allow the successful co-defendant to set up his former victory as a defense in the contribution action is at least arguably meritorious in as much as contribution and indemnity are in a sense derived rights. He has been adjudged not negligent toward the former plaintiff once and perhaps should not have to pay damages in a contribution action predicated on his joint liability to that same plaintiff. The courts, however, are split over which rule to follow in the indemnity and contribution situations. For cases holding that the former judgment conclusively establishes only the liability or non-liability of each co-defendant to the former plaintiff, see City of Mobile v. George, 253 Ala. 591, 45 So. 2d 778 (1950); Preferred Acc. Ins. Co. v. Musante, Berman \& Steinberg Co., 133 Conn. 536, 52 A.2d 862 (1947); Brown Hotel Co. v. Pittsburgh Fuel Co., 311 Ky. 396, 224 S.W.2d 165 (1949); American Motorists Ins. Co. v. Vigen, 213 Minn. 120, 5 N.W.2d 397 (1942); cf., Hobbs v. Hurley, I 7 Me. 449, ro4 Atl. 815 (1918); Gleason v. Hardware Mut. Cas. Co., 324 Mass. 695, 88 N.E.2d 632 (1949). See also Employer's Liab. Assur. Corp. v. Post \& McCord, 286 N.Y. 254, 36 N.E.2d 135 (1941). Other courts adhere to the adversary rule in both situations. See e.g., Appell v. Schneider \& Pomerantz Baking Co., x26 Conn. 16, 8 A.2d 529 (1939); Bakula v. Schwab, 167 Wis. 546, 168 N.W. 378 (1918) (dictum). However, the policies here involved are not germane to a suit predicated on independent as distinguished from derived rights, and although perhaps the adversary rule should be applied in each situation, the problems should be separately analyzed. See Bunge v. Yager, 236 Minn. 245, 52 N.W.2d 446 (1952); $c f$. Wiles v. Young, I 67 Tenn. 224, 68 S.W.2d 114 (1934); Snyder v. Marken, 116 Wash. 270, I99 Pac. 302 (r92r); I FreEMAN, op. cit. supra note 5 , at $\$ \$$ 424-25.

'See Kimmel v. Yankee Lines, 125 F. Supp. 702 (W.D. Pa. 1954), aff'd per curiam 224 F.2d 644 (3rd Cir. 1955); Lowery v. Muse, I 5 I A.2d 263 (D.C. Mun. App. 1959); Clark's Adm'x v. Rucker, 258 S.W.2d 9 (Ky. I953); Bunge v. Yager, 236 Minn. 245, 52 N.W.2d 446 (1952) ; Pearlman v. Truppo, 10 N.J. Misc. 477, 159 Atl. 623 (1932); opinion adopted ro N.J. Misc. 772, 160 Atl. 334 (1932); Wiles v. Young, 167 Tenn. 224, 68 S.W.2d II4 (1934); Byrum v. Ames \& Webb, 196 Va. 597, 85 S.E.2d 364 (1955); Snyder v. Marken, I16 Wash. 270, 199 Pac. 302 (1921); 9 Blashfield, Cyclopedia of Automobile Law and Practice \& 5835 (1955).

Some courts merely state that co-defendants are not bound. See Buhler v. Villec, I 7 So. 2d 286 (La. App. 1960), which is based on LA. Crv. Code AnN. art. 2286 (r945); Clark v. Naufel, 328 Mich. 249, 43 N.W.2d 839 (r950); Trotter v. Klein, 1 40 Misc. 78,249 N.Y. Supp. 20 (Sup. Ct. 1930).

The New York courts are in complete disagreement on the question. Compare Moran v. Lehman, 7 Misc. 2d 994, 157 N.Y.S.2d 684 (Mun. Ct. 1956), and Bennett v. Mitchell, 2 Misc. 2d 116, 15 I N.Y.S.2d 574 (Sup. Ct. 1956), with Glaser v. Huette, 232 App. Div. Ir9, 249 N.Y. Supp. 374 (193I), and Trotter v. Klein, $1_{40}$ Misc. 78 , 249 N.Y. Supp. 20 (Sup. Ct. 1930).

There is some dispute among authorities as to what constitutes adversaries. Most
} 
The adversary requirement is based on important practical considerations. Our system of procedure demands that each party be able to utilize his tactics and strategy against his opponent to the best advantage. Co-defendants, however, are often placed in a difficult position. The plaintiff chooses the time and place of trial and joins the defendants. ${ }^{8}$ Although some states permit cross-claims between co-parties, codefendants may wish to litigate their own claims in another court at a different time. ${ }^{9}$ Co-defendants should be allowed to direct their trial strategy against the plaintiff without prejudicing their right to subsequently litigate their independent claims. ${ }^{10}$ Without cross-pleadings, a

jurisdictions require cross-pleadings or an issue raised by one party to which the other can demur or enter a denial. See Clark's Adm'x v. Rucker, 258 S.W.2d 9 (Ky. r 953); Bunge v. Yager, 236 Minn. 245, 52 N.W.2d 446 (1952); Byrum v. Ames \& Webb, I 96 Va. 597, 85 S.E.2d 364 (1955); FreEMAN, op. cit. supra note 5; RestateMENT, JUDGMENTS $\$ 82$ ( 1942 ). Some expressly negate any requirement of cross-pleadings and stress the actual determination of conflicting claims between the parties. See Gleason v. Hardware Mut. Cas. Co., 324 Mass. 695, 88 N.E.2d 632 (r949) ; Godomsky v. Freeman, 120 N.J.L. I I6, I98 Atl. 391 (1938); Wright v. Schick, I 34 Ohio St. I93, 16 N.E.2d 32 I (1938); 2 Black, JUdGMENTS $\$ \$ 599,61_{4}$ (2d ed. I 902); cf., Ohio Cas. Ins. Co. v. Gordon, 95 F.2d 605 (1 oth Cir. 1938). Affidavits asserting an adverse position have also been determinative. See Vaughn's Adm'r v. Louisville \& N. R.R., 297 Ky. 309, I 79 S.W.2d 44 I (1944).

The requirement of an adverse position is of long-standing. See e.g., Buffington v. Cook, 35 Ala. 312 (I859); Cornwell v. Thompson, 50 Ill. 329 (1869); Jones v. Vert, I2I Ind. 140, 22 N.E. 882 (1889). Only a few decisions support the instant case. See Moran v. Lehman, 7 Misc. 2d 994, 157 N.Y.S.2d 684 (Mun. Ct. 1956); Bennett v. Mitchell, 2 Misc. 2d I I6, 15 I N.Y.S.2d 574 (Sup. Ct. 1956); Lumberton Coach Co. v. Stone, 235 N.C. 619, 70 S.E.2d 673 (1952).

${ }^{8}$ See Bunge v. Yager, 236 Minn. 245, 52 N.W.2d 446 (1952); Merrill v. St. Paul City Ry., I 70 Minn. 332, 2 I2 N.W. 533 (1927); cf., Pullman Co. v. Cincinnati, N.O. \& T.P. R.R., I 47 Ky. 498 , I44 S.W. ${ }_{3}^{85}$ (1912) (plaintiff joined several defendants in order to defeat removal to federal court and ignored some at trial).

Both suits are frequently in progress at the same time, and it is mere chance as to which is first concluded. In such a situation a defendant may wish to forego his appeal to concentrate on winning the suit in which he is plaintiff. Owen v. Dixon, I62 Va. 60I, I 75 S.E. 41 (1934); see Kimmel v. Yankee Lines, I25 F. Supp. 702 (W.D. Pa. I954); Wiles v. Young, I67 Tenn. 224, 68 S.W.2d 114 (1934).

- For cases applying the adversary requirement in jurisdictions permitting crossclaims see Kimmel v. Yankee Lines, 125 F. Supp. 702 (W.D. Pa. 1954); Lowery v. Muse, 151 A.2d 263 (D.C. Mun. App. 1959); Peariman v. Truppo, Io N.J. Misc. 477, I 59 Atl. 623 (1932); Byrum v. Ames \& Webb, I 96 Va. 597, 85 S.E.2d 364 (1955); Restatement, Judgments $\S 82$, comments $a-b$ (1942). It has been pointed out that an application of collateral estoppel would in effect make cross-claims compulsory where the legislature intended them to be permissive. Lowery v. Muse, supra, at 265 ; see Bunge v. Yager, 236 Minn. 245, 52 N.W.2d 446 (1952); 34 B.U.L. Rev. 104 (1954).

${ }^{10} \mathrm{Cf}$., Mickadeit v. Kansas Power \& Light Co., 174 Kan. 484,257 P.2d 156 (1953); Pearlman v. Truppo, ro N.J. Misc. 477, I59 Atl. 623 (1932); Bakula v. 
co-defendant cannot produce or cross-examine witnesses concerning the co-parties' rights inter se and, therefore, is obviously in no position to establish his co-defendant's liability to him. ${ }^{11}$ A co-defendant may also choose to default or consent to judgment due to personal motives or a small amount in controversy. ${ }^{12}$ The adversary requirement, by guarantying that only adversaries will be precluded in the future, allows co-defendants to concentrate on the plaintiff without having to weigh the effect of each move on their independent claims. The important policy implicit in the adversary requirement is perhaps best summed up by one court: "The need for expedition and conclusion in litigation is not greater than the need for opportunity for . . . the fair and full trial of an issue."13

Schwab, 167 Wis. 546, I68 N.W. 378 (1918); Von Moschzisker, Res Juticata, 38 YALE L.J. 299, 303 (1929). If each co-defendant must be concerned about the effect on future litigation with his co-party, his defense may be weakened and a plaintiff's "divide and conquer" tactics greatly facilitated.

${ }^{11}$ See Pullman Co. v. Cincinnati, N.O. \& T.P. R.R., 147 Ky. 498, x44 S.W. ${ }_{3} 85$ (1912); Godomsky v. Freeman, I20 N.J.L. 116, x98 Atl. 39x (1938); Self v. International Ry., 224 App. Div. 238, 230 N.Y. Supp. 34 (1928); Bakula v. Schwab, 167 Wis. 546, 168 N.W. 378 ( 1918 ). The theory of the defense may be inconsistent with pleadings which allow such tactics. As one court said where the plaintiff apparently operated on different theories in each case, "The evidence each offered in that suit was for the purpose of defending against the plaintiff's claim, not for the purpose of having adjudicated an issue between themselves." Byrum v. Ames \& Webb, 196 Va. 597, 60x, 85 S.E.2d 364, 366 (1955). Cf., Kimmel v. Yankee Lines, $\times 25$ F. Supp. 702 (W.D. Pa. 1954) (different lawyers in each suit).

It has been pointed out that a co-defendant cannot appeal from a ruling affecting his co-party. See Merrill v. St. Paul City Ry., I70 Minn. 332, 212 N.W. 533 (x927); Pearlman v. Truppo, xo N.J. Misc. 477, 59 Atl. 623 (1932); Bakula v. Schwab, 167 Wis. 546,168 N.W. 378 ( 1918 ).

${ }^{13}$ See note 20 infra. For similar reasons a co-defendant may not wish to defend vigorously. See Crow v. Crow, 7o Ore. 534, 139 Pac. 854 (1913) (co-defendant attempting to deprive estranged wife of interest in his property by collusive lawsuits); Von Moschzisker, supra note 1o. It is interesting to note how often the first plaintiff was a guest in the second plaintiff's automobile. The insurance company is probably silently present here. See e.g., Kimmel v. Yankee Lines, 125 F. Supp. 702 (W.D. Pa. 1954); Wiles v. Young, 167 Tenn. 224, 68 S.W.2d II4 (1934); Owen v. Dixon, x62 Va. 601, I75 S.E. 41 (1934).

${ }^{13}$ Godomsky v. Freeman, I20 N.J.L. I16, 121, 198 Atl. 391, 393 (1938).

Although often unnoticed the issue may vary slightly in the two suits. See Hellenic Lines v. The Exmouth, 253 F.2d 473 (2d Cir.) (admiralty rule of major-minor fault), cert. denied, American Export Lines v. Hellenic Lines, 356 U.S. 967 (1958); cf. Casey v. Balunas, I9 Conn. Supp. 365, I13 A.2d 867 (1955); Mickadeit v. Kansas Power \& Light Co., 174 Kan. 484, 257 P.2d 156 (1953); Godomsky v. Freeman, supra (agency determinative in the first suit). This is especially true of "last clear chance" which, although it is seldom mentioned in the opinions, would seem to be applicable to most three-way accidents. See Hardy v. Rosenthal, 2 Cal. App. 2d 442, 38 P.2d 412 (1934); 
In several jurisdictions a pleading rule forbids litigation of independent questions between co-parties. ${ }^{14}$ In North Carolina this pleading rule, juxtaposed to the court's failure to follow the adversary requirement, places co-defendants in a highly perplexing situation. They have no opportunity to determine their claims in the first suit and are prevented by collateral estoppel from doing so in any subsequent action. ${ }^{15}$ Consequently, a party may be completely denied redress in court. This last reason alone is sufficient to demand that collateral estoppel be applied only to adversaries.

The court, in addition to failing to follow the adversary requirement, apparently ignored the rule that collateral estoppel applies only to issues which have been actually litigated in a previous suit by applying the doctrine to a consent judgment. ${ }^{16}$ This result is often reached by

Capps v. Whitson, 157 Va. 46, 160 S.E. 7 × (1931). See also Prosser, Torts $\$ 52$ (2d ed. 1955).

${ }^{14}$ See Clark's Adm'x v. Rucker, 258 S.W.2d 9 (Ky. 1953); Self v. International Ry., 224 App. Div. 238, 230 N.Y. Supp. 34 (1928); Bell v. Lacey, 248 N.C. 703, ro4 S.E.2d 833 (1958); Wrenn v. Graham, 236 N.C. 719, 74 S.E.2d 232 (1953); Horton v. Perry, 229 N.C. 319,49 S.E.2d 734 (1948). Cross-actions for contribution are permitted in North Carolina. See Horton v. Perry, supra; N.C. GEN. STAT. $\$ \S$ I z22z, 1-240 (1953).

North Carolina only requires the litigant to be a party to the judgment before being bound. See Lumberton Coach Co. v. Stone, 235 N.C. 6r9, 70 S.E.2d 673 (1952); Herring v. Queen City Coach Co., 234 N.C. $5 x$, 65 S.E.2d 505 (195x). But cf., Stanley v. Parker, 207 N.C. I59, 176 S.E. 279 (1934). See also Powell v. Ingram, 23 I N.C. 427,57 S.E.2d 3:5 (1950).

${ }^{15}$ Some courts follow both this pleading rule forbidding litigation inter se and the requirement of an adversary position before applying collateral estoppel. See Clark's Adm'x v. Rucker, supra note 14 ; $c f$., Self v. International Ry., supra note $14 ; 2$ BLACK, op. cit. supra note 7 , at $\$$ 599. In these jurisdictions the doctrine of collateral estoppel should seldom apply to such an action. The only instance of a court following both rules and still applying collateral estoppel is Vaughn's Adm'r v. Louisville \& N. R.R., 297 Ky. 309, 179 S.W.2d 44I (1944), where co-defendants had submitted affidavits asserting their adverse position. For a criticism of this result see Brown Hotel Co. v. Pittsburgh Fuel Co., 3 i Ky. 396, 224 S.W.2d I65 (1949).

${ }^{16}$ See United States v. International Bldg. Co., 345 U.S. 502 (1953); Cromwell v. Sac, 94 U.S. 35I, 352-53 (1876); James, Consent Judgments as Collateral Estoppel, I08 U. PA. L. REv. I 73, 178 (1959) ; Polarsky, supra note 4, at 222; Von Moschzisker, sutpra note Io, at $30 \mathrm{x}$; RESTATEMENT, JUDGMENTS $\S 45$, comment $c$ (1942).

A court entering a consent judgment will normally determine only if the parties were capable of consenting and if they actually did consent. See Risk v. Director of Ins., 141 Neb. 488, 3 N.W.2d 922 (1942); James, supra. The court does not examine the merits of the claim but merely records the agreement; there is no actual litigation. Accord, Fruehauf Trailer Co. v. Gilmore, 167 F.2d 324 (1oth Cir. 1948); see Burgess v. Consider H. Willett, Inc., 3 II Ky. 745, 225 S.W.2d 315 (1949); Cutter v. Arlington Casket Co., 255 Mass. 52, 15 N.E. 167 (1926). There can be no appeal from a consent judgment. As an eminent jurist has said, "But neither party can complain of a consent order for the error in it, if there is any, is their own, and not 
failing to distinguish between collateral estoppel and merger and bar. ${ }^{17}$ The dissent in the instant case stresses the necessity of such a differentiation. ${ }^{18}$

Consent judgments are essentially contracts and should be so construed. ${ }^{19}$ Their similarity to contracts of settlement and release is marked, as both are important methods of compromise. ${ }^{20}$ Releases cannot be introduced in evidence in a different cause of action, ${ }^{21}$ and

the error of the court." Dora v. Lesinski, 351 Mich. 579, 582,88 N.W.2d 592, 594 (1958) (Justice Voelker quoting Judge Cooley in Chapin v. Perrin, 46 Mich. $1_{30}$, $1_{31}$, 8 N.W. $121,122(1881))$.

${ }^{17}$ See James, stapra note 16 , at 183 . The opinions simply state that res judicata applies to consent judgments. See O'Cedar Corp. v. F. W. Woolworth Co., 66 F.2d 363 (7th Cir. 1933); Partridge v. Shepard, 71 Cal. 470, 12 Pac. 480 (1886); Biggio v. Magee, 272 Mass. 185,172 N.E. 336 (1930); Stone v. Carolina Coach Co., 238 N.C. 662, 78 S.E.2d 605 (1953); Crow v. Crow, 70 Ore. 534, 139 Pac. 854 (1914); 1 FREEMAN, op. cit. supra note 5 , at $\$ 663$.

${ }^{18}$ Pack v. McCoy, 25 I N.C. 590, 595, 112 S.E.2d 118, 122 (1960).

${ }^{19}$ See Burgess v. Cousider H. Willett, Inc., 311 Ky. 745, 225 S.W.2d 315 (1949); James, supra note 16 at 175 ; Comment, Collateral Estoppel by Judgments, 52 Colum. L. REv. 647, 656 (1952); cf., Fruehauf Trailer Co. v. Gilmore, 167 F.2d 324 (Ioth Cir. 1948); State ex rel. City of St. Paul v. Great Northern Ry., 134 Minn. 249, 58 N.W. 972 (1916); LaLonde v. Hubbard, 202 N.C. 771, 164 S.W. 359 (1932). But cf., Public Serv. Elec. \& Gas Co. v. Waldroup, 38 N.J. Super. 4I9, IIg A.2d 172 (1955); 3 FREEMAN, op. cit. supra note 5, at $\$ 1350$.

${ }^{20}$ See Burgess v. Consider H. Willett, Inc, supra note 19; Gibson v. Gordon, 213 N.C. 666 , 197 S.E. 135 (1938); James, supra note 16, at 190.

Consent judgments are especially important in settling minors' claims, as they are not bound by their contracts, and an out of court settlement with a contract of release would be useless. See Daniel v. Adorno, 107 A.2d 700 (D.C. Mun. App. 1954); Pack v. McCoy, 25 I N.C. 590, I12 S.E.2d 118 (1960) (dissenting opinion); James, stipra note 16 , at 190. The situation applies to mental incompetency as well. See Gibson v. Gordon, supra.

Insurance companies also employ consent judgments frequently when representing insured defendants. See Fruehauf Trailer Co. v. Gilmore, 167 F.2d 324 (1oth Cir. 1948 ) ; Biggio v. Magee, 272 Mass. 185,172 N.E. 336 (1930). For a criticism of the latter case see James, supra note 16 , at 189 , 192; 10 B.U.L. REv. 565 (1930). This decision resulted in the passage of remedial legislation, which was unfortunately restricted to situations involving compulsory insurance. MASS. GEN, LAws ch. 23I, § I40 A (1932); see Macheras v. Syrmopoulos, 319 Mass. 485, 66 N.E.2d 351 (1946). More often the role of the insurance company is silent although it completely controls the defense. See Risk v. Director of Ins., 141 Neb. 488, 3 N.W.2d 992 (1942); Stone v. Carolina Coach Co., 238 N.C. 662, 78 S.E.2d 605 (1953); James, stipra note 16, at 191. Although the right is usually reserved in the contract, there is some conflict over the power of the insurance company to consent to judgment and the effect of such a judgment. See Annot., 32 A.I.R.2d 937 (1953). Compare Fikes v. Johnson, 220 Ark. 448, 248 S.W.2d 362 (1952), and Daniel v. Adorno, 107 A.2d yoo (D.C. Mun. App. 1954), with Long v. Union Indem. Co., 277 Mass. 428, 178 N.E. 737 (I93I).

${ }^{21}$ See 4 Wigmore, EVIDENCE $§ 1061$ (3rd ed. 1940); cf., McCormick, Evidence 
consent judgments should receive comparable treatment. ${ }^{22}$

Applying collateral estoppel to consent judgments discourages settlements by making the use of the device less desirable. ${ }^{23}$ A party will be less willing to settle small claims for fear of the effect on future litigation. ${ }^{24}$ With this rule in effect, parties are forced to settle all their claims at once or, more often, to litigate them all at the same time. ${ }^{25}$ The policy of encouraging settlements and minimizing litigation should prohibit this extension of the doctrine.

Courts today often extend the doctrine of collateral estoppel in the frequently erroneous belief that they are eliminating unnecessary litigation. ${ }^{28}$ The instant case, blindly following a single precedent, ${ }^{27}$ rejected the settled adversary rule which has long safeguarded the application of collateral estoppel. Furthermore, by failing to analyze the problems involved in consent judgments, the court, adding error to error, applied collateral estoppel to a judgment that did not result from litigation. If the court had more thoroughly analyzed the policies and practical considerations involved in the case, it would have reached a different result.

$\$ 76$ (1954). For a good statement of the rule concerning settlement and release see Penn Dixie Lines v. Grannick, 238 N.C. $552,557,78$ S.E.2d 410, 413-14 (1953).

${ }^{25}$ Accord, James, supra note 16 , at 175 ; Polarsky, supra note 4 , at 226 . Some courts while admitting the contractual nature of a consent judgment, apply collateral estoppel unless the parties agree not to apply it, cf., Public Serv. Elec. \& Gas Co. v. Waldroup, 38 N.J. Super. 419, 119 A.2d 172 (1955). Others entirely fail to see the contractual nature of the judgment. See e.g., Partridge v. Shepard, 71 Cal. 470, 12 Pac. 480 (1886); Herring v. Queen City Coach Co., 234 N.C. 5x, 65 S.E.2d 505 (1951).

${ }^{23}$ See James, supra note 16 , at I 84 ; Polarsky, supra note 4, at 228; Comment, Collateral Estoppel by Judgments, 52 Colum. L. Rev. 647, 657 (1952). But see Public Serv. Elec. \& Gas Co. v. Waldroup, 38 N.J. Super. $419,426-27$, II 9 A.2d I72, 176 (1955). For an interesting case which would discourage the use of consent judgments see Crow v. Crow, 7o Ore. 534, 139 Pac. 854 (1913).

${ }^{24}$ See Burgess v. Consider H. Willett, Inc., 3x I Ky. 745, 225 S.W.2d 315 (1949); James, supra note 16 , at 185,187 .

${ }^{25}$ A party is likely to contest every small claim or minor issue to the end if a present determination or consent judgment may be used against him in future litigation of which he is presently unaware. Cf., The Evergreens v. Nunan, I4I F.2d 927 (2d Cir.), cert. denied, 323 U.S. 720 (1944). It would seem, however, that in cases involving status, such as divorce, custody, and inz rem proceedings, consent judgments should be given collateral effect. See Jorgensen v. Jorgensen, 32 Cal. 2d 13, I8, 193 P.2d 728, 732 (1948); Polarsky, supra note 4, at 231-32; Von Moschzisker, supra note 10, at 304; $c f ., 2$ Bishop, Marriage, Divorce, and Separation $\$ 1533$ (1891). Compare, Polarsky, supra note 4 , at 250-5I. 1956).

${ }^{20}$ See, e.g., Moran v. Lehman, 7 Misc. 2d 994, I 57 N.Y.S.2d 684 (Munic. Ct.

${ }^{27}$ Lumberton Coach Co. v. Stone, 235 N.C. 619, 70 S.E,2d 673 (1952). 


\section{An Index to Modern Legal Problems}

On each of the following topies, Lat aND Conteacporary Problears has published or will publish a symposium dealing with the legal, economic, administrative, and other sociul-ycience aspects of the subject. The date indicates the year of publication.

Agricultural Adjustment in the South Air Cargo

Alcoholic Beverage Control

Alimony

Atomic Power Development

Aviation Transport

Children of Divorced Parents

Close Corporation

Collection of Real Property Taxes

Collective Bargaining Uuder the

Wagner Act

Combating the Loan Shark

Commercial Arbitration $f$

Commercial Codet

Consumption Taxes

Cooperatives

Correction of Youthful Offenders

Crime and Correction

Delivered Pricing

Divorce: A Re-examination of Basic Concepts

Emergency Price Control Act

Enemy Property

Excess Profits Taxation

Expert Testimony

Farm Tenancy Legislation

Federal Courts

Federal Employers' Liability Actt

Federal Iucome and Estate Taxation

Federal Powers Over Crime

Financial Protection for the Motor Accident Victim

Financing Small Business

Food, Drug, and Cesmetic Legislation

Governmental Marketing Barriers

Government Tort Liability

Hemispheric Trade

Home Financing

Housing

Immigration

Instalment Selling

Institutional Invostments

International Human Rightst

International Trade Barriers

Interterritorial Freight Rates

Investment of Trust Funds

Labor Dispute Settlement

Labor in Wartime

Land Planning in a Democracy
1934 Legislativo Reapportionment

1950 Literary and Artistic Products and

1940 Copyright Problems

1939 Loan Shark Problem Today

1956 Low-Cost Housing and Slum Clearanco 1934

1946 Medical Care

1944 Migratory Divorce

1953 Narcotics

1938 Obscenity and the Arts

1941 old Age Security and Welfare Titles

1952 of the Social Security Act 1930

1951 Patent System $\dagger$

1041 Presidential Office

1948 Preventive Law of Couflicts

1947,1948

1956

1956

1942 Price Control in a Cold War , 1954

1958 Price Discrimination and Price
1950 Cutting

1950 Cutting 1937

1953 Protection for the Consumer of

1945 Radio and Televisiont 1957, 1958

1943 Railroad Reorganization 1940

1935 Regulation of Insurance 1950

1937 Regulation of Natural Gas 1954

1948 Religion and the State 1949

1953 River Basin Development 1957

1940 School Pupils and the Law 1955

1934 Secured Commercial Financing 1948

Securities Act 11937

1936 Sentencing 1958

1945 Sex Offenses 1960

1939 Sherman Antitrust Act and Its
1941 Enforcement

1942 Small Business 1959

1941 State Trading $\dagger$

1938 Trade-Marks in Transition 1949

1947 Transportationt 1959, 1960

1950 "Unautborized Practice of Law"

1952 Unemployment Compensation 1936

1949 Urban Housing and Planning 1955

1946 Wage Earnors' Life Insurance 1935

1947 Wage and Hour Law 1939

1938 War Claims 1951.

1947 War Contract Renegotiation 1943

1942. War Contract Terminationt 1944

1955 Water Resources 1957

Subscriptions: $\$ 7.50$ per year ( $\$ 8.00$ foreign; $\$ 7.65$ Canada; $\$ 7.85$ Pan-America).

Single Copies: $\$ 2.50$ each (\$2.65 foreign, $\$ 2.55$ Canada, $\$ 2.60$ Pan-America). Copies of all back issues are available.

Bulle Orders: On orders for ten or more copies of a single issue a discount of 20 por cent is applicable, f.o.b. Durham, N. C.

Complete sets: Arrangements can be made to supply complete sets, unbound, at a discount of 20 per cent from the combined price for the individual issues, f.o.b. Durham, N. C.

$t$ Published in two parts, priced separately.

\section{LAW AND CONTEMPORARY PROBLEMS}

